\title{
Changes in the partial pressure of carbon dioxide in the Mauritanian-Cap Vert upwelling region between 2005 and 2012
}

\author{
Melchor González-Dávila $^{1}$, J. Magdalena Santana Casiano ${ }^{1}$, and Francisco Machín ${ }^{1,2}$ \\ ${ }^{1}$ Instituto de Oceanografía y Cambio Global, Grupo QUIMA, Universidad de Las Palmas de Gran Canaria, 35017 , \\ Las Palmas de Gran Canaria, Spain \\ ${ }^{2}$ Departamento de Física, Universidad de Las Palmas de Gran Canaria, 35017, Las Palmas de Gran Canaria, Spain \\ Correspondence to: Melchor González-Dávila (melchor.gonzalez@ulpgc.es)
}

Received: 9 March 2017 - Discussion started: 29 March 2017

Revised: 26 July 2017 - Accepted: 28 July 2017 - Published: 31 August 2017

\begin{abstract}
Coastal upwellings along the eastern margins of major ocean basins represent regions of large ecological and economic importance due to the high biological productivity. The role of these regions for the global carbon cycle makes them essential in addressing climate change. The physical forcing of upwelling processes that favor production in these areas are already being affected by global warming, which will modify the intensity of upwelling and, consequently, the carbon dioxide cycle. Here, we present monthly high-resolution surface experimental data for temperature and partial pressure of carbon dioxide in one of the four most important upwelling regions of the planet, the Mauritanian-Cap Vert upwelling region, from 2005 to 2012. This data set provides direct evidence of seasonal and interannual changes in the physical and biochemical processes. Specifically, we show an upwelling intensification and an increase of $0.6 \mathrm{Tg} \mathrm{yr}^{-1}$ in $\mathrm{CO}_{2}$ outgassing due to increased wind speed, despite increased primary productivity. This increase in $\mathrm{CO}_{2}$ outgassing together with the observed decrease in sea surface temperature at the location of the Mauritanian Cap Blanc, $21^{\circ} \mathrm{N}$, produced a $\mathrm{pH}$ rate decrease of $-0.003 \pm 0.001 \mathrm{yr}^{-1}$.
\end{abstract}

\section{Introduction}

The excess of $\mathrm{CO}_{2}$ in the atmosphere, largely responsible for global climate change, has prompted research on the role of the oceans in the carbon cycle. The aim in recent decades has been to assess how the oceans act as sources or sinks within the carbon cycle. To achieve this goal, highly resolved spatial and temporal observations representative of the distribution of $\mathrm{CO}_{2}$ fluxes between the ocean and atmosphere are necessary. Automated instruments on volunteer observing ships (VOSs) serve to provide as many observations throughout the global ocean as possible. This is in addition to data collected on scientific cruises and at long-term moorings (i.e., Astor et al., 2005: Lüger et al., 2004, 2006; González-Dávila et al., 2005, 2009; Schuster et al., 2009; Ullman et al., 2009; Watson et al., 2009; Padin et al., 2010; Gruber et al., 2002; Dore et al., 2003; Santana-Casiano et al., 2007; Bates et al., 2014).

With the amount of data already gathered (http://www. socat.info/; Pfeil et al., 2013), climatologies that present average $\mathrm{CO}_{2}$ fluxes between the atmosphere and the ocean have been developed, identifying areas acting as a source or sink (Key et al., 2004; Takahashi et al., 2009). However, the low spatial resolution of these databases limits the applicability, especially in coastal areas. Upwelling regions are particularly under-represented in such large databases. Upwelling presents a dynamic process that raises nutrient and $\mathrm{CO}_{2}$-rich water from relatively deep areas to the surface. The nutrients reaching the photic zone promote primary production, which consumes $\mathrm{CO}_{2}$. This process generates a $\mathrm{CO}_{2}$ flux into the ocean. On the other hand, upwelling also brings up $\mathrm{CO}_{2}$ from deep seawater, which generates uncertainty about the actual role of upwelling areas as a source or sink of $\mathrm{CO}_{2}$ (Michaels et al., 2001). Indeed, upwelling areas may act as a source or sink of $\mathrm{CO}_{2}$ depending on their location (Cai et al., 2006; Chen et al., 2013), where upwelling regions at low latitudes mainly act as a source of $\mathrm{CO}_{2}$ (Feely et al., 2002; Astor et al., 2005; Friederich et al., 2008; Santana-Casiano et al., 2009; González-Dávila et al., 2009) and those at midlatitudes 
mainly act as a sink of $\mathrm{CO}_{2}$ (Frankignoulle and Borges, 2001; Hales et al., 2005; Borges and Frankignoulle, 2002; Borges et al., 2005; Santana-Casiano et al., 2009; González-Dávila et al., 2009). Several anthropogenic interactive effects strongly influence eastern boundary upwelling systems (EBUSs), including upper ocean warming, ocean acidification, and ocean deoxygenation (Gruber, 2011; Feely et al., 2008; Keeling et al., 2010). Moreover, evidence of increasing wind speed that would favor upwelling (Bakun, 1990; Demarcq, 2009; Oerder et al., 2015) supports the possibility of a change in the dynamics of these highly productive areas. Recently, eddyresolving regional ocean models have shown how upwelling intensification can cause a major impact on the system's biological productivity and $\mathrm{CO}_{2}$ outgassing (Lachkar and Gruber, 2013; Oerder et al., 2015). Wind observations and reanalysis products are controversial regarding the Bakun intensification hypothesis (Bakun, 1990). Using different wind databases for the Canary region, Barton et al. (2013) concluded that there was no evidence for a general increase in the upwelling intensity off northwest Africa. Marcello et al. (2011) found an intensification of the upwelling system in the same area during a 20-year period, while the alongshore wind stress remained almost stable. Cropper et al. (2014) found that coastal summer wind speed increased, resulting in an increase in upwelling-favorable wind speeds north of $20^{\circ} \mathrm{N}$ and an increase in downwelling-favorable winds south of $20^{\circ} \mathrm{N}$. Santos et al. $(2005,2012)$ showed that sea surface temperature (SST) was not homogeneous either along latitude or longitude and depended on the upwelling index (UI) intensity. Varela et al. (2015) demonstrated opposite results worldwide depending on the length of data, season evaluated, and selected area within the same wind data set or between data sets. For the Mauritanian region, when wind stress data were used (Varela et al., 2015), a more persistent increasing trend in upwelling-favorable winds north of $21^{\circ} \mathrm{N}$ and a decreasing trend south of $19^{\circ} \mathrm{N}$ was determined.

Starting in June 2005, the QUIMA-VOS line visited the Mauritanian-Cap Vert upwelling region northwest of Africa on a monthly basis (Fig. 1 and Table S1 in the Supplement) producing for the first time a high-resolution database of SST and partial pressure of $\mathrm{CO}_{2}$ expressed as fugacity $f \mathrm{CO}_{2}$. This database shows the variations in the $\mathrm{CO}_{2}$ system under changes in the upwelling conditions in the Canary ecosystem from 27 to $10^{\circ} \mathrm{N}$ for the period 2005 to 2012 . More data for the region from other surveys exist (http://www.socat.info/; Pfeil et al., 2013) but they were not considered in this study as they do not follow the same track as the QUIMA-VOS line. Those data are strongly influenced by the distance to the upwelling cells with the corresponding physical effects in the partial pressure of $\mathrm{CO}_{2}$.

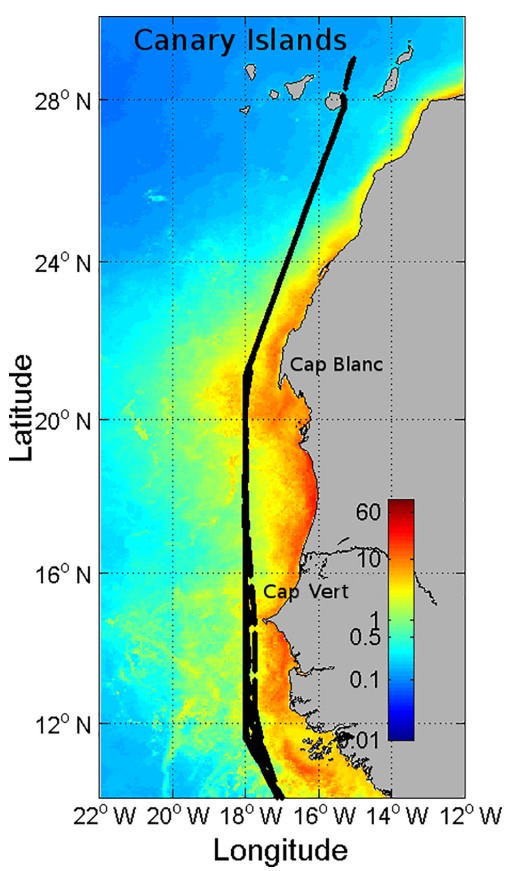

Figure 1. Ship track (black line) in the area from $28^{\circ} \mathrm{N}$ (Gran Canaria, the Canary Islands) to $10^{\circ} \mathrm{N}$. The locations of Cap Blanc and Cap Vert are indicated. Monthly OceanColor Web (https:// oceancolor.gsfc.nasa.gov/) data for average chlorophyll $a$ concentration $\left(\mathrm{mg} \mathrm{m}^{-3}\right)$ were included in a MATLAB routine and annually averaged. The map has been generated using MATLAB 7.12 R2011a.

\section{Experimental}

\subsection{Study region}

The VOS line crosses the east Atlantic Ocean from the north of Europe (English Channel) to South Africa, calling at Gran Canaria, the Canary Islands, with a periodicity of 2 months, which provides monthly data (southward or northward sections). In this work, the area between Gran Canaria at 27 and $10^{\circ} \mathrm{N}$ has been selected in order to study the MauritanianCap Vert upwelling region. On its route south (Fig. 1), the ship leaves Gran Canaria and goes straight to $100 \mathrm{~km}$ off Cap Blanc at $21^{\circ} \mathrm{N}, 17^{\circ} 45^{\prime} \mathrm{W}$. It then follows this longitude, passing at $100 \mathrm{~km}$ off Cap Vert until $12^{\circ} \mathrm{N}$, where it changes direction to Cape Town, reaching $10^{\circ} \mathrm{N}, 17^{\circ} \mathrm{W}$ at $330 \mathrm{~km}$ off the coast of Guinea. Between 22 and $20^{\circ} \mathrm{N}$, the ship reaches the $500 \mathrm{~m}$ isobath. South of $15^{\circ} \mathrm{N}$, the ship moves between the 1000 and $500 \mathrm{~m}$ isobaths. On its route north, the ship follows the reverse track.

\subsection{Experimental data}

Experimental data were obtained under the EU projects CARBOOCEAN and CARBOCHANGE (www.CarboOcean.org and https://carbochange.b.uib.no/) and now also available at http://www.socat.info/ (Pfeil et al., 
2013). An autonomous instrument for the determination of the partial pressure of $\mathrm{CO}_{2}$ developed by Craig Neill following NOAA recommendations was installed on a VOS line. This was operated by the Mediterranean Shipping Company S.A. from 2005 to 2008 and Maersk from 2010 to 2012. This VOS line (QUIMA-VOS) ran between the UK and Cape Town from July 2005 to January 2013 (Table S1 in the Supplement). Temperature was measured at three positions along the sampling circuit: in the intake (Sea-Bird SBE38L), in the equilibrator (Sea-Bird thermosalinograph SBE21 and internal PT100 thermometer), and in the oxygen sensor

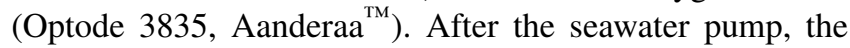
intake is divided into two lines, one feeding the $\mathrm{CO}_{2}$ system and the other feeding the oxygen sensor, the fluorometer, and the Sea-Bird thermosalinometer. Differences between equilibrator and intake temperatures were constant in time due to the high seawater flow but varied among ships due to the different locations of the equipment. Values varied between $0.06^{\circ} \mathrm{C}$ when the equipment was placed close to the intake and $0.35^{\circ} \mathrm{C}$ when the equipment was one floor above and inside the engine room. The SST was also obtained from the NOAA_OI_SST-V2 data provided by the NOAA/OAR/ESRL PSD from Boulder, Colorado, USA (http://www.esrl.noaa.gov/psd). These data had a spatial resolution of $1^{\circ}$ latitude and $1^{\circ}$ longitude and monthly averages were used. The correlation between our experimental SST data and satellite data was better than $\pm 1{ }^{\circ} \mathrm{C}$, and improved to $\pm 0.4^{\circ} \mathrm{C}$ after removing the most affected upwelling regions $\left(19-22\right.$ and $\left.14-16^{\circ} \mathrm{N}\right)$, which related to the high variability imposed by the upwelling.

The $\mathrm{CO}_{2}$ molar fraction, $x \mathrm{CO}_{2}$, was obtained every $150 \mathrm{~s}$ in seawater, while atmospheric $x \mathrm{CO}_{2}$ data were obtained every $180 \mathrm{~min}$. The seawater intake was located at a $10 \mathrm{~m}$ depth. The system was calibrated every 3 hours by measuring four different standard gases with mixing ratios in the ranges of $0.0,250-290,380-410$, and $490-530 \mathrm{ppm}$ of $\mathrm{CO}_{2}$ in the air, provided by NOAA and traceable to the World Meteorological Organization scale. The precision of the system is greater than $0.5 \mu \mathrm{atm}$ and the accuracy estimated with respect to the standard gases is of $1 \mu \mathrm{atm}$ inside the standards' range. For $x \mathrm{CO}_{2}$ values higher than the highest standard $(532.04 \mathrm{ppm})$, the accuracy will be reduced, even when linearity was observed in all cases inside the standards range. The fugacity of $\mathrm{CO}_{2}\left(f \mathrm{CO}_{2}\right.$, $\left.\mu \mathrm{atm}\right)$ was calculated from $x \mathrm{CO}_{2}$ after correcting for temperature differences between intake and equilibrator, according to the expressions for seawater given by DOE (1994). Normalized $f \mathrm{CO}_{2}\left(\mathrm{~N} f \mathrm{CO}_{2}\right)$ derived from the mean SST for the area $\left(T_{\text {mean }}\right)$ was computed following Takahashi et al. (1993) as

$$
\left(\mathrm{N} f \mathrm{CO}_{2}\right)=f \mathrm{CO}_{2} \cdot \exp \left[0.0423\left(T_{\text {mean }}-\mathrm{SST}\right)\right] .
$$

In order to compute a second carbonate system variable, the surface total alkalinity $\left(A_{T}\right)$ was computed from sea surface salinity (SSS) and SST (Lee et al., 2006). $\mathrm{pH}_{T}$ at the in situ temperature was computed from $f \mathrm{CO}_{2}$ and $A_{T}$ and with average annual surface ocean total phosphate and total silicate concentrations of 0.5 and $4.8 \mu \mathrm{mol} \mathrm{kg}{ }^{-1}$, respectively, from the World Ocean Atlas 2009, using the carbonic acid acidity constants by Mehrbach et al. (1973) refitted by Dickson and Millero (1987).

Air-sea $\mathrm{CO}_{2}$ fluxes $\left(\mathrm{FCO}_{2}, \mathrm{mmol} \mathrm{m}^{-2} \mathrm{~d}^{-1}\right)$ were evaluated as

$\mathrm{FCO}_{2}=0.24 \cdot k \cdot s \cdot\left(f \mathrm{CO}_{2}^{\mathrm{sw}}-f \mathrm{CO}_{2}^{\mathrm{atm}}\right)$,

where 0.24 is the scale factor, $k$ is the gas transfer velocity, $s$ is the $\mathrm{CO}_{2}$ solubility, $f \mathrm{CO}_{2}^{\mathrm{sw}}$ is the seawater fugacity of $\mathrm{CO}_{2}$, and $f \mathrm{CO}_{2}^{\text {atm }}$ is the atmospheric fugacity of $\mathrm{CO}_{2}$. In order to evaluate $\left(f \mathrm{CO}_{2}^{\mathrm{sw}}-f \mathrm{CO}_{2}^{\mathrm{atm}}\right), f \mathrm{CO}_{2}^{\mathrm{atm}}$ data were linearly interpolated to the $f \mathrm{CO}_{2}^{\mathrm{sw}}$ time vector. A positive value for $\mathrm{FCO}_{2}$ corresponds to $\mathrm{CO}_{2}$ outgassing from the ocean. $k$ $\left(\mathrm{cm} \mathrm{h}^{-1}\right)$ was evaluated with the following parameterization (Nightingale et al., 2000):

$k=\left(0.222 \cdot W^{2}+0.333 \cdot w\right) \cdot(S c / 660)^{-1 / 2}$,

where $W$ is the wind speed at $10 \mathrm{~m}$ above the sea surface $\left(\mathrm{m} \mathrm{s}^{-1}\right)$ and $S c$ is the Schmidt number.

The variables involved in estimating $\mathrm{FCO}_{2}$ data (i.e., $f \mathrm{CO}_{2}^{\mathrm{sw}}, f \mathrm{CO}_{2}^{\mathrm{atm}}$, SST, and SSS) were fitted to sinusoidal expressions (Lüger et al., 2004) for a given latitude as follows:

$$
\begin{aligned}
X(\text { lat })^{*} & =a_{0}+a_{1}(t-2005)+a_{2} \sin (2 \pi t)+a_{3} \cos (2 \pi t) \\
& +a_{4} \sin (4 \pi t)+a_{5} \cos (4 \pi t),
\end{aligned}
$$

where $a_{i}$ are the fitting coefficients, $t$ is the sampling time expressed as year fraction, and $X(\text { lat })^{*}$ represents any of the four fitted variables. This procedure allowed us to reconstruct the series of experimental data for periods without monthly data. The variables were decomposed into an interannual term $X(\text { lat })_{t}^{*}=a_{0}+a_{1}(t-2005)$ plus a periodical term $X(\text { lat })_{\mathrm{p}}^{*}=a_{2} \sin (2 \pi t)+a_{3} \cos (2 \pi t)+a_{4} \sin (4 \pi t)+$ $a_{5} \cos (4 \pi t)$, that is, $X(\text { lat })^{*}=X(\text { lat })_{t}^{*}+X(\text { lat })_{\mathrm{p}}^{*}$. The periodical term accounts for the high-frequency seasonal variability, while the interannual term marks the year-to-year trend. First, observations were grouped in a natural year for a given latitude, as if they had been taken in a single year (no correction was done for interannual variability). The mean seasonal climatology data associated with the periodic coefficients (i.e., $a_{2}, a_{3}, a_{4}$, and $a_{5}$ ) throughout the sampling period were determined. Next, the interannual coefficient $a_{1}$ was calculated by fitting the residuals resulting from subtracting the periodical component, $X(1 \mathrm{at})_{\mathrm{p}}^{*}$, from the original variable $X$ (lat). By fixing these five coefficients $\left(a_{1}-a_{5}\right)$, new distributions for $f \mathrm{CO}_{2}^{\mathrm{sw} *}, f \mathrm{CO}_{2}^{\mathrm{atm} *}$, $\mathrm{SST}^{*}$, and $\mathrm{SSS}^{*}$ were constructed with a daily resolution based on the curve fits given for each variable as in Eq. (4), providing the coefficient $a_{0}$. The accuracy of this fitting procedure was checked by both computing the correlation between experimental and reconstructed values and by determining the mean residuals. The Pearson coefficients were always over 0.87 for 
SST (average $0.94 \pm 0.03$ ), over 0.69 for both $f \mathrm{CO}_{2}^{\text {sw }}$ and $f \mathrm{CO}_{2}^{\text {atm }}$ (average of $0.79 \pm 0.07$ and $0.82 \pm 0.04$, respectively), and over 0.67 for SSS (average $0.79 \pm 0.07$ ). The mean residual on the determination of those four variables were $\pm 3.7 \mu \mathrm{atm}, \pm 1.5 \mu \mathrm{atm}, \pm 0.22^{\circ} \mathrm{C}$, and \pm 0.05 for $f \mathrm{CO}_{2}^{\mathrm{sW} *}, f \mathrm{CO}_{2}^{\mathrm{atm} *}, \mathrm{SST}^{*}$, and $\mathrm{SSS}^{*}$, respectively. When the monthly satellite SST values were considered, the new SST* function averaged for each month produced values within $\pm 0.47^{\circ} \mathrm{C}$, confirming that this procedure was able to fit nonsampled periods. It was assumed that the same procedure was valid for non-sampled $f \mathrm{CO}_{2}$. Finally, daily $\mathrm{FCO}_{2}^{*}$ time series between 10 and $27^{\circ} \mathrm{N}$ with a latitudinal resolution of $0.5^{\circ}$ were calculated with a standard error of estimation of $0.5 \mathrm{mmol} \mathrm{m}^{-2} \mathrm{~d}^{-1}$ (15\% of error) that produced mean residuals (experimental $\mathrm{FCO}_{2}-\mathrm{FCO}_{2}^{*}$ ) of $0.4 \mathrm{mmol} \mathrm{m}^{-2} \mathrm{~d}^{-1}$ and Pearson correlation coefficients between experimental and computed $\mathrm{FCO}_{2}^{*}$ of $r>0.6, p<0.01$.

Chlorophyll $a$ was calculated from measurements made by the Moderate-resolution Imaging Spectroradiometer (MODIS) aboard NASA's Aqua satellite. We used monthly averages with a spatial resolution of $9 \mathrm{~km}$ supplied by OceanColor Web (https://oceancolor.gsfc.nasa.gov).

Wind data were downloaded from the NCEP CFSR database at http://rda.ucar.edu/pub/cfsr.html developed by NOAA and retrieved from the NOAA National Operational Model Archive and Distribution System and maintained by the NOAA National Climatic Data Center. The spatial resolution is approximately $0.3 \times 0.3^{\circ}$ and the temporal resolution is $6 \mathrm{~h}$. The reference height for the wind data is $10 \mathrm{~m}$.

Rainfall data were collected by the precipitation radar installed on the Tropical Rainfall Measuring Mission (TRMM) satellite (http://precip.gsfc.nasa.gov). Monthly averages with a spatial resolution of $0.5 \times 0.5^{\circ}$ (product $3 \mathrm{~A} 12$, version 07 ) were used (Fig. S1 in the Supplement) in order to explain changes in seasonal surface salinity distributions.

\section{Results and discussion}

\subsection{Physical properties}

The variability of the Mauritanian-Cap Vert upwelling was analyzed in terms of the upwelling index (Nykjaer and Van Camp, 1994) (Fig. 2) using satellite wind data. Negative UI values correspond to upwelling-favorable conditions and positive values to downwelling-favorable conditions. The lowest negative values of the index correspond to more intense upwelling. Results clearly distinguish two main subareas in the upwelling system: (1) north of $20^{\circ} \mathrm{N}$, the upwelling conditions were favorable throughout the year, although the highest upwellings were observed from March to September with a northward shift from 20 to $22^{\circ}$ N. (2) South of $20^{\circ} \mathrm{N}$, a marked seasonality was observed with favorable upwelling conditions during autumn and winter, with the maximum intensity observed during January and February. In this

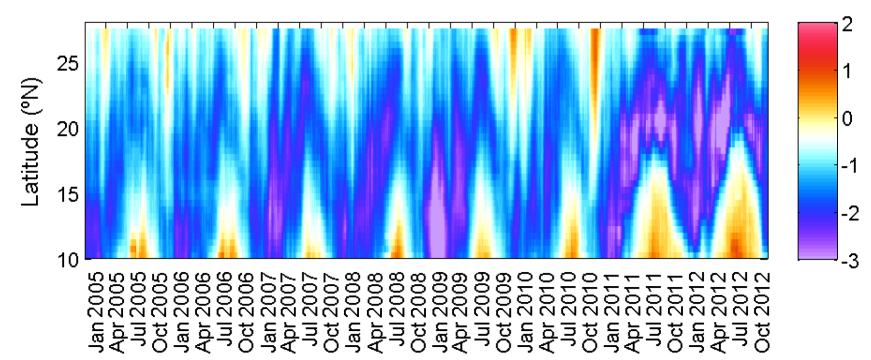

Figure 2. Time series of upwelling index (UI, $\times 10^{-3} \mathrm{~m}^{2} \mathrm{~s}^{-1}$ ) in the Mauritanian-Cap Vert upwelling region along the ship track computed following Nykjaer and Van Camp (1994). Blue colors are related to upwelling events and red colors to downwelling events.

region, a downwelling regime is present between May and November when the summer trade winds are replaced by the monsoonal winds advecting warm water (Fig. 3a) northward along the shore (Nykjaer and Van Camp, 1994). Our results (Fig. 2) are quite consistent with previous research (Nykjaer and Van Camp, 1994; Marcello et al., 2011; Santos et al., 2005, 2012; Cropper et al., 2014) but include the years 2010 to 2012 , when the UI at around $20-21^{\circ} \mathrm{N}$ presented a shift of the upwelling intensity from high $\left(-2000 \mathrm{~m}^{2} \mathrm{~s}^{-1}\right)$ to strong $\left(-2800 \mathrm{~m}^{2} \mathrm{~s}^{-1}\right)$. The analysis of upwelling trends along this route has been controversial since it is highly dependent on the selected region (Santos et al., 2012). The interannual evolution of the UI over the period 2005 to 2012 (Fig. 4, green line) for each degree in latitude indicates an increase in the UI (mean confidence interval of $9 \mathrm{~m}^{2} \mathrm{~s}^{-1}$ ) as showed by Santos et al. (2012).

North of $15^{\circ} \mathrm{N}$, the upwelling index confirmed the stronger upwelling observed since 1995-1996 in this region after more than a 10-year (from at least 1982 to 1995) period of weaker upwelling (Santos et al., 2012). Local zonal differences between ocean and coastal SST trends determined with satellite data confirmed the intensification of the upwelling regime along the African coast for the period 1982 to 2000 (Santos et al., 2005) and extended by Santos et al. (2012) until 2010 and further extended in this study until 2012 (data not shown). This has been described as a decadal-scale shift of the upwelling regime intensity (Marcello et al., 2011; Santos et al., 2012).

South of $15^{\circ} \mathrm{N}$, the annual UI values and trends (Figs. 2 and 4) both for the upwelling (values close to $-2800 \mathrm{~m}^{2} \mathrm{~s}^{-1}$ in January) and downwelling (values reaching $1850 \mathrm{~m}^{2} \mathrm{~s}^{-1}$ in July) periods are becoming stronger. At $11-12^{\circ} \mathrm{N}$, where downwelling is becoming stronger, this results in negative annual temperature rates that approach zero. The UI serves as an indication of decadal variability of the summer monsoon winds and associated northward advection of warm water along the coast (Santos et al., 2012).

The highest upwelling intensity along the VOS line was located at the capes, Cap Blanc and Cap Vert. From satellite chlorophyll $a$ data, especially off Cap Blanc, giant fila- 
(a)
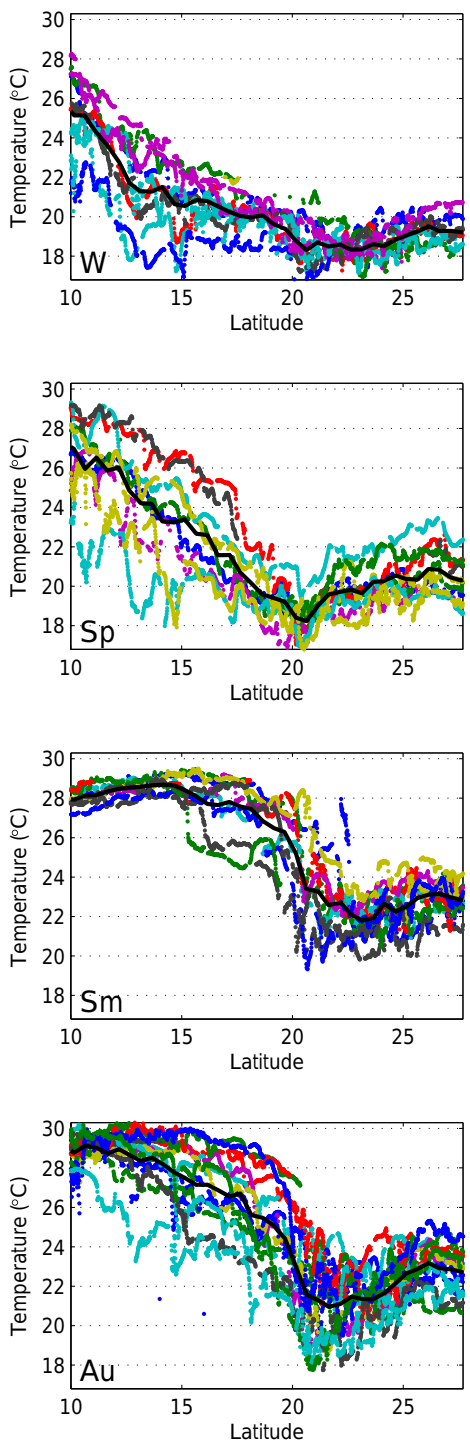

(b)
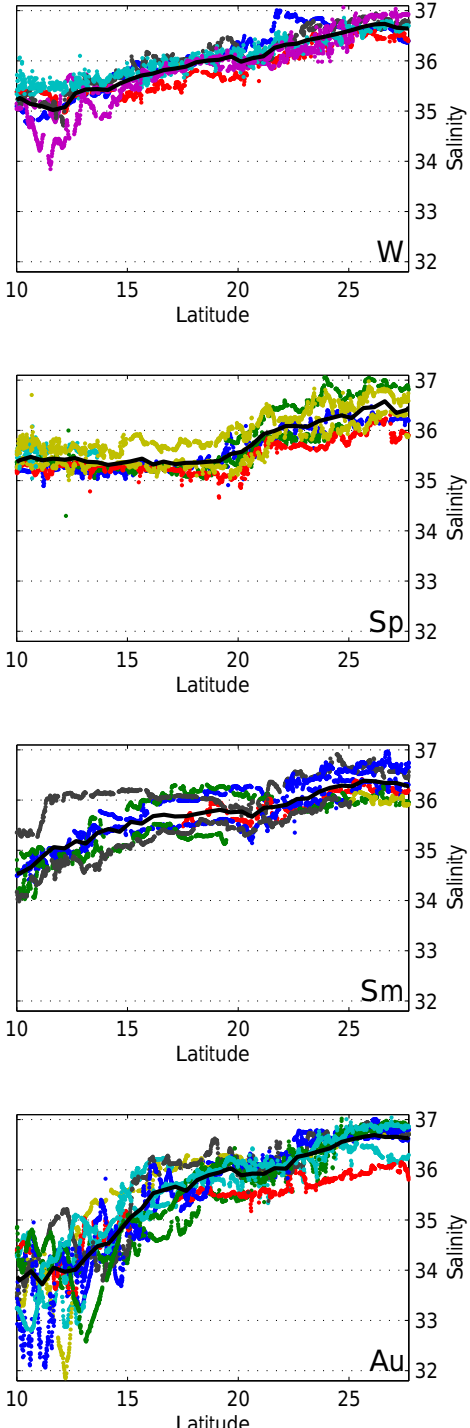

Figure 3. In situ data of column (a) SST and column (b) SSS in the Mauritanian-Cap Vert coastal region grouped by seasons: winter (W; December, January, and February), spring (Sp; March, April, and May), summer (Sm; June, July, and August), and autumn (Au; September, October, and November). The averaged values for all cruises in Table S1 are shown in black for each season including the $95 \%$ confidence limits. The color code for each cruise is indicated in Table S1.

ments with chlorophyll concentrations above $1 \mathrm{mg} \mathrm{m}^{-3}$ persist year-round, spreading from the coast to several hundred kilometers offshore (Fig. 1). North of Cap Blanc the upwelled water originates from the North Atlantic Central Water, and mixes with South Atlantic Central Water (SACW) towards the south (Mittelstaedt, 1983). South of Cap Blanc, the upwelling of nutrient-rich SACW (Mittelstaedt, 1983) promotes phytoplankton growth between Cap Blanc and Cap Vert. Towards $12^{\circ} \mathrm{N}$, upwelling is also fed by the North Equatorial Undercurrent (Hagen and Schemainda, 1984). Moreover, the entire northwest African coast is also influenced by the African desert dust transport by the midtropospheric Harmattan winds originating from the central
Sahara, which supplements the levels of micronutrients (such as iron) to the adjacent marine ecosystem (Mittelstaedt, 1983; Neuer et al., 2004).

The study area is also affected by the migration of the Intertropical Convergence Zone (ITCZ), related to maximum precipitation rates (Hastenrath, 1995). To have a significant satellite precipitation record in our region of interest, precipitation data were integrated longitudinally between 25.25 and $9.75^{\circ} \mathrm{W}$. Time series for the latitudinal distribution of integrated precipitation (Fig. S1 in the Supplement) identified the average position of the ITCZ related to maximum precipitation rates. The ITCZ was located at its southernmost position $\left(2^{\circ} \mathrm{N}\right)$ during winter, reaching its northernmost position 

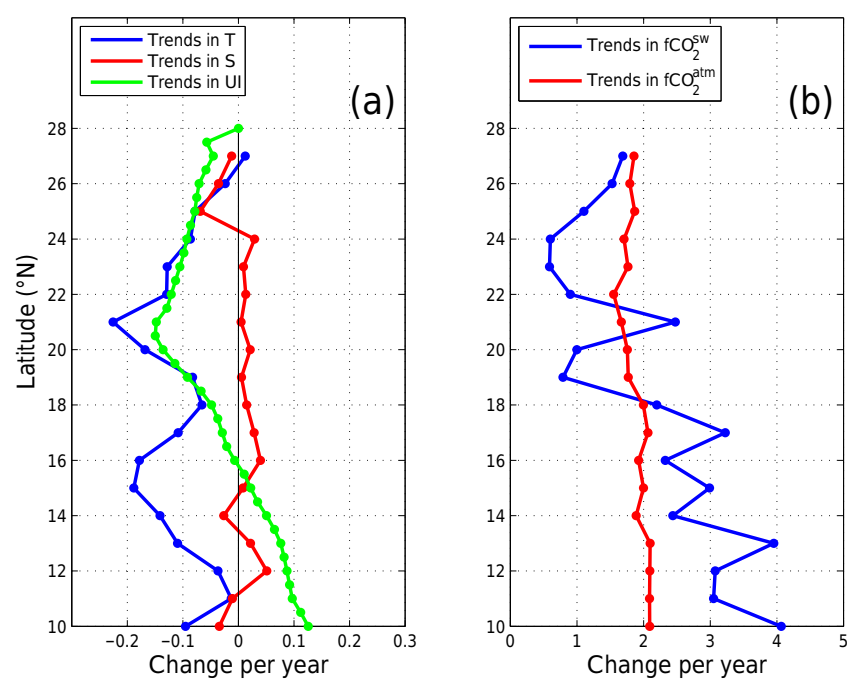

Figure 4. Latitudinal distribution of the interannual trends for the upwelling index (UI) and for the four experimental variables along the QUIMA-VOS line integrated over every degree between 2005 and 2012. Panel (a) presents the trends for upwelling index (UI, $\times 10^{-3} \mathrm{~m}^{2} \mathrm{~s}^{-1}$, mean confidence interval of $9 \mathrm{~m}^{2} \mathrm{~s}^{-1}$ ), SST $\left({ }^{\circ} \mathrm{C} \mathrm{yr}^{-1}\right.$, confidence interval $\left.0.13^{\circ} \mathrm{C}\right)$, and SSS $\left(\mathrm{yr}^{-1}\right.$, confidence interval 0.06) and (b) the trends for $f \mathrm{CO}_{2}^{\mathrm{sw}}$ and $f \mathrm{CO}_{2}^{\mathrm{atm}}$ (confidence intervals 4.23 and $0.44 \mu \mathrm{atm})$.

$\left(14-16^{\circ} \mathrm{N}\right)$ around summer. The ITCZ reached our area of interest $\left(>10^{\circ} \mathrm{N}\right)$ from late spring to late summer.

The latitudinal distributions of measured SST and SSS along the vessel track are shown in Fig. 3, grouped by seasons (labeled W, Sp, Sm, and $\mathrm{Au}$ ). The temperature generally decreased from $10^{\circ} \mathrm{N}$ to about $20-21^{\circ} \mathrm{N}$, where the ship meets the Mauritanian upwelling. From there to the north, the temperature rises as the ship leaves the upwelling area on its way to the Canary Islands. In situ temperature at $27^{\circ} \mathrm{N}$ shows temperatures in the range of 18 to $24^{\circ} \mathrm{C}$ with the minimum in winter and maximum in late summer to early autumn. The annual temperature range was somewhat higher at $20^{\circ} \mathrm{N}$, with a summer maximum of around $26^{\circ} \mathrm{C}$ and minimum in spring of about $17^{\circ} \mathrm{C}$. At $10^{\circ} \mathrm{N}$, temperatures were the highest throughout the year $\left(>25^{\circ} \mathrm{C}\right)$, with minimum values in winter and maximum in late spring and late autumn. The low values observed during the end of summer are related to the arrival of the ITCZ (Fig. S1 in the Supplement) at those latitudes. The thermal distribution shows a temperature increase as we move to the Equator and a notable cooling at the upwelled waters off Mauritania. The upwelling of cold water from the Cap Vert area was only detected during winter time and the beginning of spring. Salinity minimum values were normally located at $10^{\circ} \mathrm{N}$, increasing to maximum values at the Canaries' latitude. The minimum values of salinity were exceptionally low during autumn from 10 to $16^{\circ} \mathrm{N}$ by both the freshwater input from rivers that increase their outflow during this season (Nicholson, 1981) and by the northward shift of the ITCZ during this time of the year.

Anomaly fields for temperature and salinity (data not shown) were calculated as the difference between the observations and the mean values at each season for individual latitudes. For temperature, the largest anomalies in winter and spring were located south of $18^{\circ} \mathrm{N}$, with values of $\pm 2{ }^{\circ} \mathrm{C}$, related to the seasonal cycle of the Cap Vert upwelling. During summer the pattern changed and the largest anomalies were detected in the upwelling area at $18-22^{\circ} \mathrm{N}$, with values of $\pm 5^{\circ} \mathrm{C}$ when the upwelling index for the Mauritanian area was highest (Fig. 2). In autumn the temperature anomalies were shifted slightly to the north, $20-24^{\circ} \mathrm{N}$, with values of $\pm 3^{\circ} \mathrm{C}$ related to the observed pulses in upwelling-favorable winds that affected the surface seawater properties. On the other hand, salinity anomalies showed a very homogeneous pattern in all latitudes for winter, spring, and summer, with values generally within \pm 0.5 . However, during autumn important anomalies south of $18^{\circ} \mathrm{N}$ were observed, with values in the range of \pm 1.5 . In this region, the upwelling development, the river discharge, and the rainy season controlled the observed distribution (Yoo and Carton, 1990).

To conclude, the data show a permanent annual upwelling regime observed north of $20^{\circ} \mathrm{N}$ and a seasonal regime across $10-19^{\circ} \mathrm{N}$, in accordance with the climatology of previous studies. The data also confirm an increase in upwelling conditions north of $20^{\circ} \mathrm{N}$ and an increase in downwelling conditions south of $20^{\circ} \mathrm{N}$.

\subsection{Carbon dioxide variability}

The latitudinal distribution of the seasonal $f \mathrm{CO}_{2}^{\mathrm{sw}}$ data (Fig. 5a) showed the highest values between 18 and $23^{\circ} \mathrm{N}$ for all seasons due to the variability imposed by the upwelling off Mauritania. $f \mathrm{CO}_{2}^{\mathrm{sw}}$ was consistently greater than the $f \mathrm{CO}_{2}^{\mathrm{atm}}$. During winter, when the Cap Vert upwelling develops (Fig. 2), the $12-15^{\circ} \mathrm{N}$ region also presented higher $f \mathrm{CO}_{2}^{\mathrm{sw}}$ values than those in the atmosphere. $f \mathrm{CO}_{2}^{\mathrm{sw}}$ data showed a latitudinal shift between the seasons following the shift observed in the upwelling index: in winter, the largest values were located between 19 and $24^{\circ} \mathrm{N}$; in spring, they were located between 16 and $22^{\circ} \mathrm{N}$; and during summer and autumn, the largest $f \mathrm{CO}_{2}^{\mathrm{sw}}$ values were recorded in the range 20 to $23^{\circ} \mathrm{N}$. The difference between $f \mathrm{CO}_{2}^{\text {sw }}$ normalized to the mean SST of $22^{\circ} \mathrm{C}$ for the region $\left(\mathrm{N} f \mathrm{CO}_{2}^{\mathrm{sw}}\right)$ and $f \mathrm{CO}_{2}^{\mathrm{sw}}$ $\left(\Delta f \mathrm{CO}_{2}=\mathrm{N} f \mathrm{CO}_{2}^{\mathrm{sw}}-f \mathrm{CO}_{2}^{\mathrm{sw}}\right.$, Fig. 5b) reinforced the variability at $20-23^{\circ} \mathrm{N}$ all year around and at $12-17^{\circ} \mathrm{N}$ during winter and spring, indicating that upwelling is the major factor contributing to the $f \mathrm{CO}_{2}$ variability.

According to Takahashi et al. (1993), $f \mathrm{CO}_{2}^{\mathrm{sw}}$ increases with temperature at a rate of $4.3 \% \mu^{\circ}{ }^{\circ} \mathrm{C}^{-1}$ (between 15 and $26 \mu \mathrm{atm}^{\circ} \mathrm{C}^{-1}$ in this area) in a thermodynamically controlled system. At $27^{\circ} \mathrm{N}$, as SST increases, the rate was only $7.45 \mu$ atm ${ }^{\circ} \mathrm{C}^{-1}$ due mainly to biological uptake and also to $\mathrm{CO}_{2}$ outflux. At $20^{\circ} \mathrm{N}$ the rate became negative with a value 
(a)
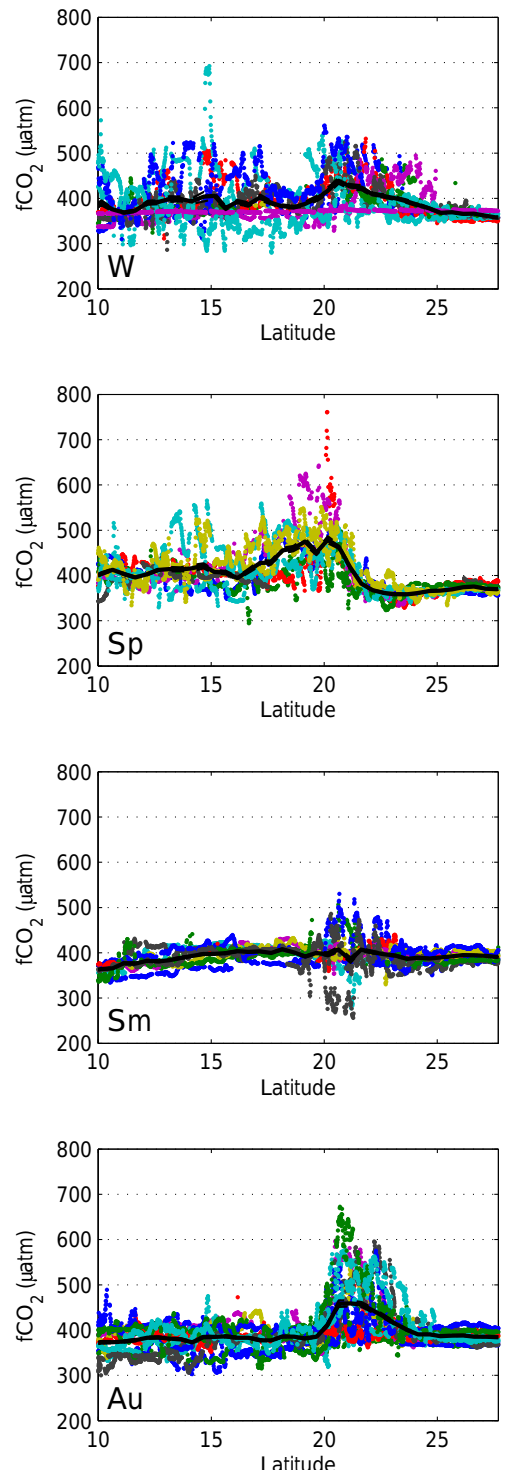

(b)
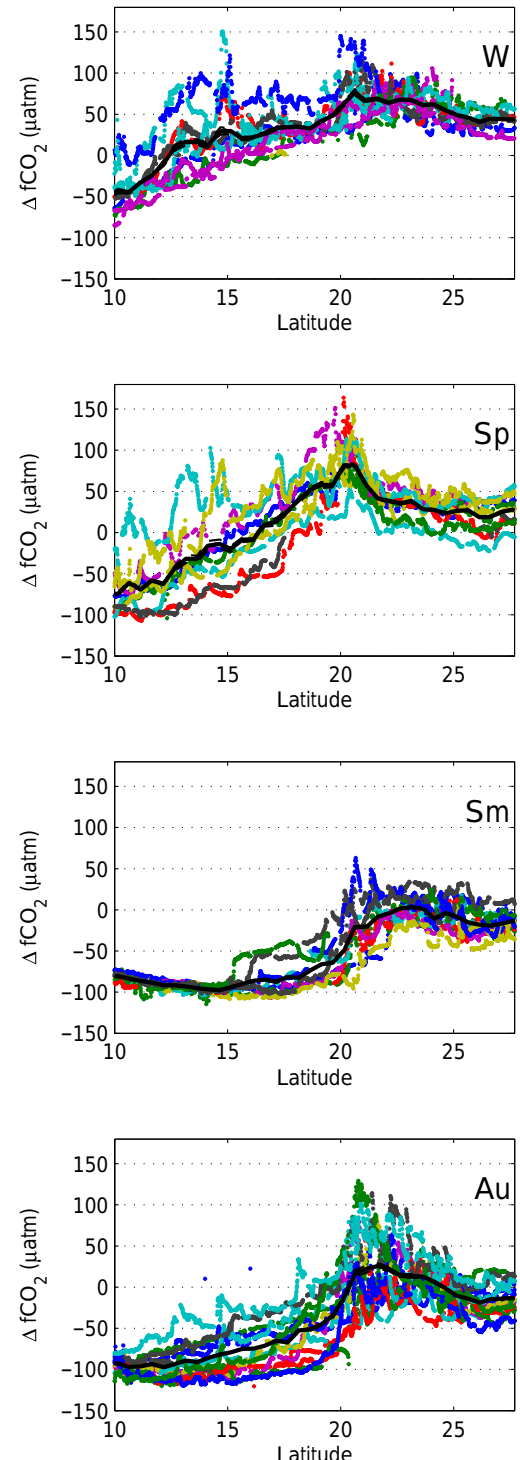

Figure 5. Fugacity of $\mathrm{CO}_{2}$ data in the Mauritanian-Cap Vert coastal region grouped by seasons: winter (W; December, January, and February), spring (Sp; March, April, and May), summer (Sm; June, July, and August), and autumn (Au; September, October, and November). Column (a) $f \mathrm{CO}_{2}^{\mathrm{sw}}$ latitudinal distribution. Column (b), difference between measured and $f \mathrm{CO}_{2}^{\mathrm{sw}}$ values normalized to a constant temperature of $22{ }^{\circ} \mathrm{C}$. The averaged values for all cruises in Table S1 are shown in black for each season including the $95 \%$ confidence limits. The color code for each cruise is indicated in Table S1.

of $-10.9 \mu$ atm ${ }^{\circ} \mathrm{C}^{-1}$, clearly indicating the important injection of cool and $\mathrm{CO}_{2}$-rich seawater at the upwelling area. The injection is not being compensated for by the solubility nor by the biological carbon pumps. At $10^{\circ} \mathrm{N}$, the rate was still negative but only $-4.3 \mu \mathrm{atm}{ }^{\circ} \mathrm{C}^{-1}$ as a result of the seasonal upwelling. $\mathrm{N} f \mathrm{CO}_{2}^{\text {sw }}$ was related with SST (data not shown) in order to account for effects not removed during normalization. At latitudes 19 to $21^{\circ} \mathrm{N}$, in the upwelling vicinity of Cap Blanc, an inverse relationship of $70-100 \mu a \mathrm{am}^{\circ} \mathrm{C}^{-1}$ was found during winter and spring, while in summer and autumn the inverse relationship rate was reduced to 12 $18 \mu$ atm ${ }^{\circ} \mathrm{C}^{-1}$. While the upwelling indexes at those latitudes were quite constant throughout the year, different rates observed should be related to biological consumption of the $\mathrm{CO}_{2}$ excess. However, during winter and spring the injection of $\mathrm{CO}_{2}$ in the upwelling is not decreased by the biological activity in the area. But during the Chlorophyll $a$ maximum (late spring and summer), most of the $\mathrm{CO}_{2}$ was consumed and/or exported and, therefore, the rate was strongly reduced. 
Figure 4 depicts the observed interannual trends ( $a_{1}$ coefficient in Eq. 4) for the four experimentally recorded detrended parameters, together with the UI trend. Confidence intervals of the computed mean annual values for SST, SSS, $f \mathrm{CO}_{2}^{\text {atm }}$, and $f \mathrm{CO}_{2}^{\mathrm{sw}}$ were $0.13^{\circ} \mathrm{C}, 0.06,0.44$, and $4.23 \mu \mathrm{atm}$, respectively. There was a clear SST trend whereby seawater along the VOS line track was getting cooler with maximum cooling rates at the location of Cap Blanc $\left(21^{\circ} \mathrm{N}\right)$ and Cap Vert upwellings $\left(15^{\circ} \mathrm{N}\right)$ with rates higher than $-0.2{ }^{\circ} \mathrm{Cyr}^{-1}$. Data from the first 3 years (2005 to 2008) at $21^{\circ} \mathrm{N}$ showed lower temperatures with higher cooling rates that reached $-0.7^{\circ} \mathrm{C} \mathrm{yr}^{-1}$, although 3 years of data are not representative. The area crossed by the VOS line along $17^{\circ} 45^{\prime} \mathrm{W}$ from 22 to $10^{\circ} \mathrm{N}$ is located inside the $1000 \mathrm{~m}$ isobath that is well inside the mean frontal activity in the Canary region, about $200 \mathrm{~km}$ wide (Wang et al., 2015). The different changes in temperature in the coastal slope and offshore waters are related to the different origins of the waters upwelled from depths of about $100 \mathrm{~m}$ to the surface (Mittelstaedt, 1983) that spread off the coastal area. The offshore water SST is less variable owing to longer residence time in the ocean surface. These effects and the fact that the VOS line keeps a track line that crossed the upwelling cells at a distance to the coast that varies among cells contribute to the observed spatial variability. There was no attempt to compare latitudinal and longitudinal effects on the observed values. Our experimental data, however, do not show any positive SST rates in the upwelling affected area, and only when the ship approached the Canary Islands did the trends become less negative, reaching a value of $+0.02^{\circ} \mathrm{C} \mathrm{yr}^{-1}$ at $27^{\circ} \mathrm{N}$, similar to those obtained for oceanic Atlantic water (Bates et al., 2014).

$f \mathrm{CO}_{2}^{\text {atm }}$ for the area showed the interannual increase of about $2 \pm 0.3 \mu \mathrm{atm} \mathrm{yr}^{-1}$ observed in atmospheric stations, while $f \mathrm{CO}_{2}^{\mathrm{sw}}$ presented a heterogeneous distribution. South of $18^{\circ} \mathrm{N}$, the rate of increase was always higher than that in the atmosphere reaching a maximum value of $4.1 \pm 0.4 \mu \mathrm{atm} \mathrm{yr}{ }^{-1}$ at $10^{\circ} \mathrm{N}$. At $27^{\circ} \mathrm{N}, f \mathrm{CO}_{2}^{\mathrm{sw}}$ increased at a rate of $1.7 \pm 0.2 \mu \mathrm{atm} \mathrm{yr}^{-1}$ similar to that determined at the ESTOC time series site (González-Dávila et al., 2010) located at $29^{\circ} 10^{\prime} \mathrm{N}, 15^{\circ} 30^{\prime} \mathrm{W}$. In the Cap Blanc area, $f \mathrm{CO}_{2}^{\mathrm{sw}}$ increased at an average rate of $2.5 \pm 0.4 \mu \mathrm{atm} \mathrm{yr}{ }^{-1}$ with the highest values in the period 2005 to 2008 (a rate of $4.6 \pm 0.5 \mu \mathrm{atm} \mathrm{yr}^{-1}$ was computed with only those years). Around Cap Blanc, $f \mathrm{CO}_{2}^{\text {sw }}$ always presented lower rates of increase than in the atmosphere with values well below $1 \mu \mathrm{atm} \mathrm{yr}^{-1}$. The observed decrease in SST and the trends in $f \mathrm{CO}_{2}^{\text {sw }}$ can only be explained by a reinforced upwelling. North of $18^{\circ} \mathrm{N}$, the lowest rate of increase in $f \mathrm{CO}_{2}^{\mathrm{sw}}$ compared to $f \mathrm{CO}_{2}^{\text {atm }}$, together with a decrease in temperature, indicated that upwelling is also favoring an increase in the net community production around the Mauritanian upwelling, consuming and/or exporting the $\mathrm{CO}_{2}$-rich upwelled waters favored by the lateral transport of the Mauritanian current (Lachkar and Gruber, 2013; Varela et al., 2015). The

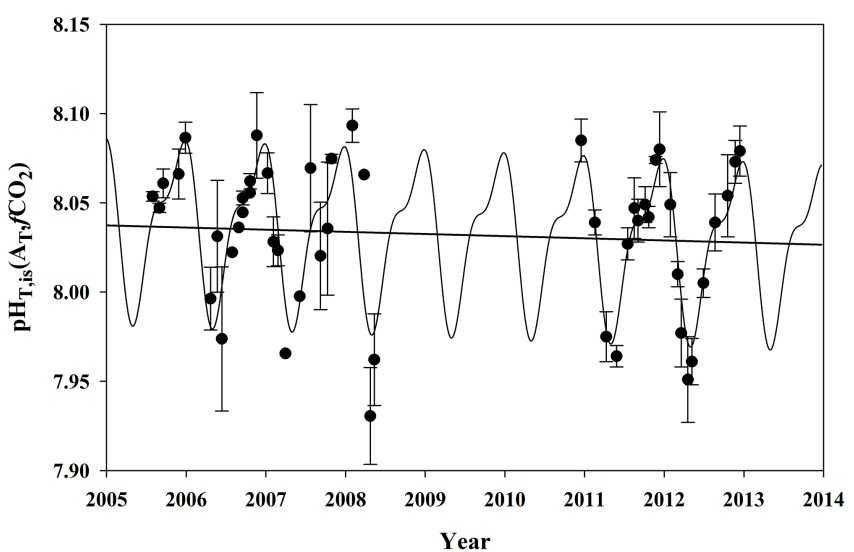

Figure 6. $\mathrm{pH}$ of surface waters in total proton scale and at in situ SST computed from total alkalinity (based on regional correlations with SST and SSS; Lee et al., 2006) and $f \mathrm{CO}_{2}$ at $21 \pm 0.25^{\circ} \mathrm{N}$. The error bars represent the standard deviation of the computed data for each cruise for the selected latitude. The black curve shows the harmonic fitting of Eq. (4) for the data and the corresponding linear trend is also shown.

upwelling intensification effects observed in the trends of our experimental data support the recent wind stress trends (Cropper et al., 2014; Varela et al., 2015; Santos et al., 2012) of increased upwelling-favorable winds, at least for the period 2005-2012 in the Canary upwelling region (Figs. 2 and 4). The intensification of the upwelling results in a change in the measured upwelled water properties due to either higher upwelling velocities or deeper source upwelled waters. However, what remains unclear from these records is to what extent those changes reflect upwelling variations due to climate change forcing versus natural decadal variability in the upwelling areas occurring over interannual timescales.

Because the upwelling intensity is changing, other variables will also be affected. $\mathrm{pH}_{T}$, is at $21 \pm 0.25^{\circ} \mathrm{N}$ was computed from $f \mathrm{CO}_{2}$ and alkalinity pairs of data. Alkalinity was computed from regional correlations with SST and SSS (Lee et al., 2006), which could underrepresent seasonal and interannual variations in upwelling areas. However, $\mathrm{pH}$ computed from $f \mathrm{CO}_{2}$ values are relatively insensitive to errors in $A_{T}$, and $f \mathrm{CO}_{2}$ controls the magnitude and variability of $\mathrm{pH}$ (a $60 \mu \mathrm{mol} \mathrm{kg}^{-1}$ change in $A_{T}$ will affect a $0.1 \%$ in $\mathrm{pH}$, that is, about $0.01 \mathrm{pH}$ units). Figure 6 depicts the computed $\mathrm{pH}_{T \text {,is }}\left(A_{T}, f \mathrm{CO}_{2}\right)$ data and the harmonic fitting of Eq. (4) providing the seasonal variability and interannual trend. Considering the small systematic biases in interannual dynamics, we determined a decrease in $\mathrm{pH}$ at a rate of $-0.003 \pm 0.001 \mathrm{yr}^{-1}$ (Fig. 6). This decrease is one of the highest rate values determined in several time series stations (Bates et al., 2014), where oceanic SST has only slightly increased in the last decades. However, at the Mauritanian upwelling area and at the location where our VOS line approached this region, SST decreased at a rate of $-0.22 \pm 0.06^{\circ} \mathrm{Cyr}^{-1}$ (Fig. 4). Solely 

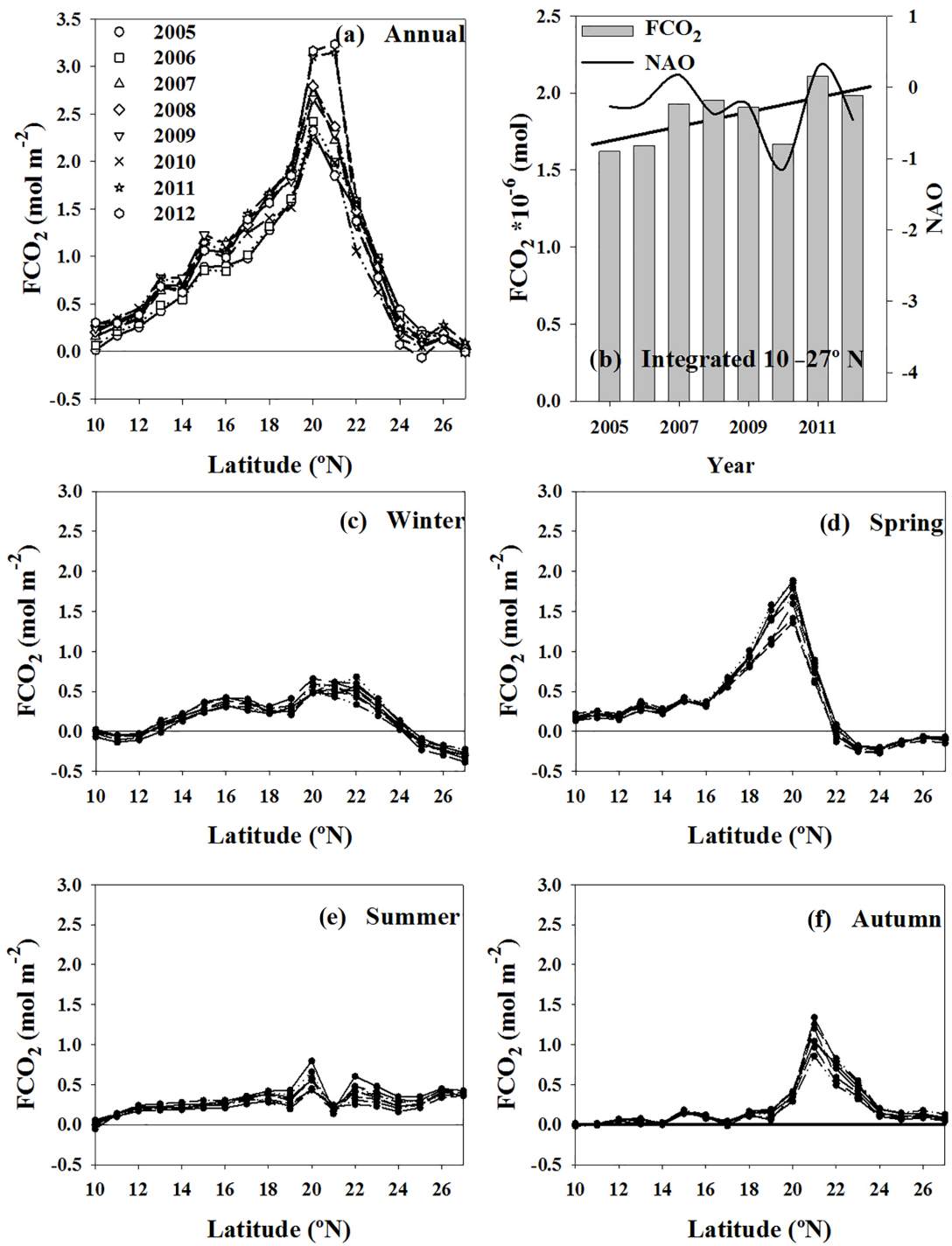

Figure 7. Latitudinal distributions of seasonal and annual $\mathrm{CO}_{2}$ fluxes $\left(\mathrm{FCO}_{2}, \mathrm{~mol} \mathrm{~m}^{-2}\right)$. Fluxes of $\mathrm{CO}_{2}$ were computed using Nightingale et al. (2000) parameterization and satellite winds with a resolution of $6 \mathrm{~h}$. (a) Integrated year to year from 2005 to 2012 and (b) latitudinally integrated for 2005 to 2012 together with annual values for the North Atlantic Oscillation (NAO) index. Latitudinal distributions of $\mathrm{FCO}_{2}$ seasonally integrated from 2005 to 2012 are depicted for (c) winter (December, January, and February), (d) spring (March, April, and May), and (e) summer (June, July, and August).

this decrease in temperature would increase the $\mathrm{pH}$ by a rate of $+0.004 \mathrm{yr}^{-1}$ and the $f \mathrm{CO}_{2}$ would decrease by $4 \mu \mathrm{atm} \mathrm{yr}^{-1}$. The net effect of the increase in the amount of rich $\mathrm{CO}_{2}$ and lower $\mathrm{pH}$ upwelled waters in the Mauritanian upwelling would be, therefore, a decrease in the $\mathrm{pH}$ rate of over $-0.007 \pm 0.002$ units $\mathrm{yr}^{-1}$ and an increase in $f \mathrm{CO}_{2}$ of $+6.5 \pm 0.7 \mu \mathrm{atm} \mathrm{yr}^{-1}$ (with periods where those rates could reach values of $-0.015 \mathrm{yr}^{-1}$ in $\mathrm{pH}$ and $+10.5 \mu \mathrm{atm} \mathrm{yr}^{-1}$ in $f \mathrm{CO}_{2}$ as recorded during 2005-2008). Those values are greatly compensated for by the important decrease in the SST resulting in the determined rates of $-0.003 \pm 0.001 \mathrm{pH}$ units and $+2.5 \pm 0.4 \mu$ atm of $f \mathrm{CO}_{2}$ per year.
This new data set of experimental values confirmed a decrease in SST and trends in $f \mathrm{CO}_{2}^{\mathrm{sw}}$ that can only be explained by reinforced upwelling conditions that favor an increase in the net community production around the Mauritanian upwelling together with a more corrosive environment with $\mathrm{pH}$ rates that change by more than $-0.007 \pm 0.002 \mathrm{yr}^{-1}$ at $21^{\circ} \mathrm{N}$. However, the decrease in SST in the upwelling cell buffers this $\mathrm{pH}$ rate to values around $-0.003 \pm 0.001 \mathrm{yr}^{-1}$ and $+2.5 \pm 0.4 \mu \mathrm{atm} \mathrm{yr}^{-1}$ in $f \mathrm{CO}_{2}$, still among the highest observed in other time series. 


\subsection{Fluxes of $\mathrm{CO}_{2}$}

The annual air-sea $\mathrm{CO}_{2}$ flux for the full domain was positive (Fig. 7a), with the area off Cap Blanc with values close to $3.3 \mathrm{molCO}_{2} \mathrm{~m}^{-2}$ (Fig. 7a). North of $24^{\circ} \mathrm{N}$, in the area not affected by the coastal upwelling, an average flux of $+0.14 \pm 0.03 \mathrm{molCO}_{2} \mathrm{~m}^{-2}$ was determined. The ingassing observed during winter and spring of $-0.16 \pm 0.03 \mathrm{~mol} \mathrm{CO}_{2} \mathrm{~m}^{-2}$ for the full period (Fig. 7) was surpassed by the outgassing during summer and autumn of $0.28 \pm 0.14 \mathrm{molCO}_{2} \mathrm{~m}^{-2}$. South of $24^{\circ} \mathrm{N}$, it was observed that during spring (Fig. 7d) the photosynthetic activity was not intense enough to uptake the $\mathrm{CO}_{2}$ injected by the strongest upwelling in the surface waters and thus the area acted as a source of $\mathrm{CO}_{2}$ with values reaching $1.9 \mathrm{~mol} \mathrm{CO}_{2} \mathrm{~m}^{-2}$ in 2012. During summer (Fig. 7e), primary producers and lateral advection of warm waters by the Mauritanian current could consume and/or export the $\mathrm{CO}_{2}$ rich waters reaching values of $0.5 \mathrm{~mol} \mathrm{CO}_{2} \mathrm{~m}^{-2}$. During autumn (Fig. 7f), only the area between 20 and $23^{\circ} \mathrm{N}$ acted as a source of $1-1.5 \mathrm{~mol} \mathrm{CO}_{2} \mathrm{~m}^{-2}$, while the rest was almost in equilibrium. Late autumn-winter upwelling in the 14 to $17^{\circ} \mathrm{N}$ region contributed to an increased outgassing with a second annual submaximum of about $0.4 \mathrm{~mol} \mathrm{CO}_{2} \mathrm{~m}^{-2}$ in winter (Fig. 7c). South of $14^{\circ} \mathrm{N}$, annual $\mathrm{CO}_{2}$ fluxes decreased from about $0.7 \mathrm{~mol} \mathrm{CO}_{2} \mathrm{~m}^{-2}$ at $14^{\circ} \mathrm{N}$ to being roughly in equilibrium at $10^{\circ} \mathrm{N}$.

The integrated $\mathrm{CO}_{2}$ fluxes for the area between 10 and $27^{\circ} \mathrm{N}$ along the VOS line section for the years 2005 to 2012 (Fig. 7b) were between 1.6 and $2.1 \times 10^{6} \mathrm{~mol}$ of $\mathrm{CO}_{2}$, with an important annual variability. $\mathrm{FCO}_{2}$ increased during the studied period by $0.05 \pm 0.02 \times 10^{6} \mathrm{~mol} \mathrm{yr}^{-1}$. The increase in $\mathrm{FCO}_{2}$ is related to the observed increase in wind speed (Fig. 4, indicated as UI) north of $16^{\circ} \mathrm{N}$. North of $19^{\circ} \mathrm{N}$, the influence of wind speed far surpassed the effect of the smaller annual rate of increase in $f \mathrm{CO}_{2}^{\text {sw }}$ relative to $f \mathrm{CO}_{2}^{\text {atm }}$, with an exception at $21^{\circ} \mathrm{N}$ (Fig. 4). South of $16^{\circ} \mathrm{N}$, the decrease in wind speed did not exceed the effect of the incremental change in $\left(f \mathrm{CO}_{2}^{\mathrm{sw}}-\right.$ $f \mathrm{CO}_{2}^{\text {atm }}$ ) associated with the increased downwelling indexes (Fig. 4; Santos et al., 2012), resulting in a slightly increasing $\mathrm{FCO}_{2}$. The variability observed in the annual integrated $\mathrm{CO}_{2}$ fluxes (Fig. 7b) was related with the basin-scale oscillations, the North Atlantic Oscillation (NAO) index and the east Atlantic pattern (EA) (http://www.cpc.ncep.noaa. Gov/data/teledoc/telecontents.shtml). Cropper et al. (2014) found winter upwelling variability was strongly correlated with the winter NAO ( $r$ values ranged from 0.50 at $12-19^{\circ} \mathrm{N}$ to 0.59 at $21-26^{\circ} \mathrm{N}$ ), due to the influence of the Azores semipermanent high-pressure system on the strength of the trade winds. The annual integrated $\mathrm{FCO}_{2}$ was related with the annual NAO index (Fig. 7b) with a similar $r=0.54$, even when fluxes are not only controlled by wind strength. However, Fig. 7a clearly indicates that the Mauritanian upwelling area was the most important contributor to $\mathrm{FCO}_{2}$ in the study area. The $\mathrm{FCO}_{2}$ was not significantly correlated with the winter NAO $(r=0.23)$. Also, the EA index, which represents a southward-shifted NAO-like oscillation, presented a lower significant value ( $r=0.48)$ (trends not shown), in agreement with the upwelling index (Cropper et al., 2014). Overall, the correlation between fluxes and climate indexes describing the main mode of variability across the Atlantic sector may be directly related to the Azores High and its influence on the trade wind strength.

$\mathrm{FCO}_{2}$ values along the QUIMA-VOS line were used in order to compute a flux budget for the Mauritanian-Cap Vert region. The observed values were assumed to be valid for at least $100 \mathrm{~km}$ on both sides of the QUIMA-VOS line. In this case, the total flux of $\mathrm{CO}_{2}$ being ejected to the atmosphere would reach a value of $16 \mathrm{Tg}$ of carbon dioxide a year for the period 2005-2012, with a rate of increase of $+0.6 \mathrm{Tg} \mathrm{yr}^{-1}$. However, it should be considered that the export of the rich $f \mathrm{CO}_{2}$ upwelled water with high nutrient concentration off the coastal areas would promote a decrease in surface $f \mathrm{CO}_{2}$ values during productive seasons (as those observed north and south of $21^{\circ} \mathrm{N}$ ) that will result in an ingassing of $\mathrm{CO}_{2}$. This could balance the observed outgassing increase on a more global scale.

\section{Conclusions}

The Mauritanian-Cap Vert upwelling area's sensitivity to climatic forcing on upwelling processes strongly affects the $\mathrm{CO}_{2}$ surface distribution, ocean acidification rates, and airsea $\mathrm{CO}_{2}$ exchange.

The experimental SST and carbon dioxide system variable results for the period 2005 to 2012 confirm upwelling intensification at the Mauritanian-Cap Vert upwelling system. Furthermore, we have shown that upwelling regions at low to midlatitudes are important sources of $\mathrm{CO}_{2}$ for the atmosphere. As a direct result, the $\mathrm{pH}$ is decreasing at a rate of $-0.003 \pm 0.001 \mathrm{yr}^{-1}$. Importantly, the amount of emitted $\mathrm{CO}_{2}$ is increasing annually at a rate of $0.6 \mathrm{Tg}$ due to stronger wind stress, even when primary production seems to also be enhanced in the upwelling area. The monthly record in this EBUS is not yet long enough to determine the extent to which these changes can be attributed to natural decadal variability. These VOS lines must be maintained for years to come and will continue to be one of the most significant contributors to our knowledge of how ocean surface waters are being affected by present and future climate change. The results from VOS lines can provide accurate data for changes in SST, $\mathrm{FCO}_{2}$, and, consequently, upwelling intensification effects due to global change conditions under decadal natural variability.

Data availability. All data are freely available at the SOCAT database, http://www.socat.info/ (Pfeil et al., 2013), and at the CAR- 
BOOCEAN and CARBOCHANGE web pages, www.CarboOcean. org and https://carbochange.b.uib.no/, respectively.

\section{The Supplement related to this article is available online at https://doi.org/10.5194/bg-14-3859-2017-supplement.}

Author contributions. MGD and JMSC worked in the equipment installation, data collection and designed the study. FM processed the data and generated figures and results. All of them collaborated in the discussion of the data and the writing of the paper.

Competing interests. The authors declare that they have no conflict of interest.

Special issue statement. This article is part of the special issue "The Ocean in a High- $\mathrm{CO}_{2}$ World IV". It is a result of the 4th International Symposium on the Ocean in a High- $\mathrm{CO}_{2}$ World, Hobart, Australia, 3-6 May 2016.

Acknowledgements. Financial support from the European Union through the integrated project FP6 CARBOOCEAN under grant agreement no. 511106-2, FP7 project CARBOCHANGE under grant agreement no. 264879 and H2020 project ATLANTOS under agreement no. 633211 is gratefully acknowledged. Special thanks go to the Mediterranean Shipping Company (MSC) (years 2005-2008) and Maersk (years 2010-2013), who provided the ship platforms and scientific facilities. We thank April Abbott (Macquarie University, Sydney) for her comments and English correction. The MODIS-Aqua Ocean Color Data, 2005-2012 reprocessing, NASA OB.DAAC, Greenbelt, MD, USA, is strongly acknowledged.

Edited by: Kai G. Schulz

Reviewed by: two anonymous referees

\section{References}

Astor, Y., Scranton, M., Muller-Karger, F., Bohrer, R. N., and Garcia, J.: $\mathrm{CO}_{2}$ variability at the CARIACO tropical coastal upwelling time series station, Mar. Chem., 97, 245-261, 2005.

Bakun, A.: Global climate change and intensification of coastal ocean upwelling, Science, 247, 198-201, 1990.

Barton, E. D., Field, D. B., and Roy, C.: Canary current upwelling: More or less?, Prog. Oceanogr., 116, 167-178, 2013.

Bates, N. R., Astor, Y. M., Church, M. J., Currie, K., Dore, J. E., González-Dávila, M., Lorenzoni, L., Muller-Karger, F., Olafsson, J., and Santana-Casiano, J. M.: A time-series view of changing ocean chemistry due to ocean uptake of anthropogenic $\mathrm{CO}_{2}$ and ocean acidification, Oceanography, 27, 126141, https://doi.org/10.5670/oceanog.2014.16, 2014.
Borges, A. V. and Frankignoulle, M.: Distribution of surface carbon dioxide and air-sea exchange in the upwelling system off the Galician coast, Global Biogeochem. Cy., 16, 1020, https://doi.org/10.1029/2000GB001385, 2002.

Borges, A. V., Delille, B., and Frankignoulle, M.: Budgeting sinks and sources of $\mathrm{CO}_{2}$ in the coastal ocean: Diversity of ecosystems counts, Geophys. Res. Lett., 32, L14601, https://doi.org/10.1029/2005GL023053, 2005.

Cai, W.-J., Dai, M., and Wang, Y.: Air-sea exchange of carbon dioxide in oceanmargins: aprovince-based synthesis, Geophys. Res. Lett., 33, L12603, https://doi.org/10.1029/2006GL026219, 2006.

Chen, C.-T. A., Huang, T.-H., Chen, Y.-C., Bai, Y., He, X., and Kang, Y.: Air-sea exchanges of $\mathrm{CO}_{2}$ in the world's coastal seas, Biogeosciences, 10, 6509-6544, https://doi.org/10.5194/bg-106509-2013, 2013.

Cropper, T. E., Hanna, E., and Bigg, G. R.: Spatial and temporal seasonal trends in coastal upwelling off NorthwestAfrica, 19812012, Deep-Sea Res. Pt. I, 86, 94-111, 2014.

Demarcq, H.: Trends in primary production, sea surface temperature and wind in upwelling systems (1998-2007), Prog. Oceanogr., 83, 376-385, https://doi.org/10.1016/j.pocean.2009.07.022, 2009.

Dickson, A. G. and Millero, F. J.: A comparison of the equilibrium constants for the dissociation of carbonic acid in seawater media, Deep-Sea Res., 34, 1733-1743, 1987.

DOE: Handbook of methods for the analysis of the various parameters of the carbon dioxide system in sea water, ORNL/CDIAC74, available at: http://cdiac.ornl.gov/oceans/handbook.html (last access: 7 March 2017), 1994.

Dore, J. E., Lukas, R., Sadler, D. W., and Karl, D. M.: Climatedriven changes to the atmospheric $\mathrm{CO}_{2}$ sink in the subtropical North Pacific Ocean, Nature, 424, 754-757, 2003.

Feely, R. A., Boutin, J., Cosca, C. E., Dandonneau, Y., Etcheto, J., Inoue, H. Y., Ishii, M., Quéré, C. L., Mackey, D. J., McPhaden, M., Metzl, N., Poisson, A., and Wanninkhof, R.: Seasonal and interannual variability of $\mathrm{CO}_{2}$ in the equatorial Pacific, Deep Sea Res. Pt. II, 49, 2443-2469, 2002.

Feely, R. A., Sabine, C. L., Hernandez-Ayon, J. M., Ianson, D., and Hales, B.: Evidence for upwelling of corrosive "acidified" water onto the continental shelf, Science, 320, 1490-1492, https://doi.org/10.1126/science.1155676, 2008.

Frankignoulle, M. and Borges, A. V.: European continental shelf as a significant sink for atmospheric carbon dioxide, Global Biogeochem. Cy., 15, 569-576, 2001.

Friederich, G. E., Ledesma, J., Ulloa, O., and Chavez, F. P.: Air-sea carbon dioxide fluxes in the coastal southeastern tropical Pacific, Prog. Oceanogr., 79, 156-166, 2008.

González Dávila, M., Santana-Casiano, M. J., Merlivat, L., Barbero-Munoz, L., and Dafner, E.: Fluxes of $\mathrm{CO}_{2}$ between the atmosphere and the ocean during the POMME project in the northeast Atlantic Ocean during 2001, J. Geophys. Res., 110, C07S11, https://doi.org/10.1029/2004JC002763, 2005.

González-Dávila, M., Santana-Casiano, J. M., and Ucha, I.: Seasonal variability of $\mathrm{fCO}_{2}$ in the Angola-Benguela region, Prog. Oceanogr., 83, 124-133, 2009.

González-Dávila, M., Santana-Casiano, J. M., Rueda, M. J., and Llinás, O.: The water column distribution of carbonate system variables at the ESTOC site from 1995 to 2004, Biogeosciences, 7, 3067-3081, https://doi.org/10.5194/bg-7-3067-2010, 2010. 
Gruber, N.: Warming up, turning sour, losing breath: ocean biogeochemistry under global change, Philos. T. R. Soc. Lond., 369, 1980-1996, 2011.

Gruber, N., Keeling, C. D., and Bates, N. R.: Interannual variability in the North Atlantic Ocean carbon sink, Science, 298, 23742378, 2002.

Hagen, E. and Schemainda, R.: Der Guineadom im ostatlantischen Stromsystem, Beitr. Meereskd., 51, 5-27, 1984.

Hales, B., Takahashi, T., and Bandstra, L.: Atmospheric $\mathrm{CO}_{2}$ uptake by a coastal upwelling system, Global Biogeochem. Cy., 19, GB1009, https://doi.org/10.1029/2004GB002295, 2005.

Hastenrath, S.: Climate Dynamics of the Tropics, 488 pp., Kluwer Acad., Norwell, Mass., 1995.

Keeling, R. F., Kortzinger, A., and Gruber, N.: Ocean deoxygenation in a warming world, Annu. Rev. Mar. Sci., 2, 199-229, https://doi.org/10.1146/annurev.marine.010908.163855, 2010.

Key, R., Kozyr, A., Sabine, C., Lee, K., Wanninkhof, R., Bullister, J., Feely, R., Millero, F. J., Mordy, C., and Peng, T.-H.: A global ocean carbon climatology: Results from GLODAP, Global Biogeochem. Cy., 18, GB4031, https://doi.org/10.1029/2004GB002247, 2004.

Lachkar, Z. and Gruber, N.: Response of biological production and air-sea $\mathrm{CO}_{2}$ fluxes to upwelling intensificationin the California and Canary Current Systems, J. Marine Syst., 109-110, 149-160, 2013.

Lee, K., Tong, L. T., Millero, F. J., Sabine, C. L., Dickson, A. G., Goyet, C., Park, G. H., Wanninkhof, R., Feely, R. A., and Key, R. M.: Global relationships of total alkalinity with salinity and temperature in surface waters of the world's oceans, Geophys. Res. Lett., 33, L19605, https://doi.org/10.1029/2006GL027207, 2006.

Lüger, H., Wallace, D. W., Körtzinger, A., and Nojiri, Y.: The $p \mathrm{CO}_{2}$ variability in the midlatitude North Atlantic Ocean during a full annual cycle, Global Biogeochem. Cy., 18, GB3023, https://doi.org/10.1029/2003GB002200, 2004.

Lüger, H., Wanninkhof, R., Wallace, D. W., and Körtzinger, A.: $\mathrm{CO}_{2}$ fluxes in the subtropical and subarctic North Atlantic based on measurements from a volunteer observing ship, J. Geophys. Res., 111, C06024, https://doi.org/10.1029/2005JC003101, 2006.

Marcello, J., Alonso, H., Eugenio, F., and Fonte, A.: Seasonal and temporal study of the northwest African upwelling system, Int. J. Remote Sens., 32, 1843-1859, https://doi.org/10.1080/01431161003631576, 2011.

Mehrbach, C., Culberson, C. H., Hawley, J. E., and Pytkowicz, R. N.: Measurement of the apparent dissociation constants of carbonic acid in seawater at atmospheric pressure, Limnol. Oceanogr., 18, 897-907, 1973.

Michaels, A. F., Karl, D. M., and Capone, D. G.: Element stoichiometry, new production and nitrogen fixation, Oceanography, 14, 68-77, 2001.

Mittelstaedt, E.: The upwelling area off Africa - A description of phenomena related to coastal upwelling, Prog. Oceanogr., 12, 307-331, https://doi.org/10.1016/0079-6611(83)90012-5, 1983.

Neuer, S., Torres-Padrón, M. E., Gelado-Caballero, M. D., Rueda, M. J., Hernández-Brito, J. J., Davenport, R., and Wefer, G.: Dust deposition pulses to the eastern subtropical North Atlantic gyre: Does ocean's biogeochemistry respond?, Global Biogeochem. Cy., 18, GB4020, https://doi.org/10.1029/2004GB002228, 2004.
Nicholson, S. E.: Rainfall and atmospheric circulation during drought periods and wetter years in West Africa, Mon. Weather Rev., 109, 2191-2208, 1981.

Nightingale, P. D., Malin, G., Law, C. S., Watson, A. J., Liss, P. S., Liddicoat, M. L., Boutin, J., and Upstill-Goddard, R. C: In situ evaluation of air-sea gas exchange parameterizations using novel conservative and volatile tracers, Global. Biogeochem. Cy., 14, 373-387, 2000.

Nykjaer, L. and Van Camp, L.: Seasonal and interannual variability of coastal upwelling along Northwest Africa and Portugal from 1981 to 1991, J. Geophys. Res., 99, 14197-14207, 1994.

Oerder, V., Colas, F., Echevin, V., Codron, F., Tam, J., and Belmadani, A.: Peru-Chile upwelling dynamics under climate change, J. Geophys. Res.-Oceans, 120, 1152-1172, https://doi.org/10.1002/2014JC010299, 2015.

Padin, X. A., Vázquez-Rodríguez, M., Castaño, M., Velo, A., Alonso-Pérez, F., Gago, J., Gilcoto, M., Álvarez, M., Pardo, P. C., de la Paz, M., Ríos, A. F., and Pérez, F. F.: Air-Sea $\mathrm{CO}_{2}$ fluxes in the Atlantic as measured during boreal spring and autumn, Biogeosciences, 7, 1587-1606, https://doi.org/10.5194/bg-7-15872010, 2010.

Pfeil, B., Olsen, A., Bakker, D. C. E., Hankin, S., Koyuk, H., Kozyr, A., Malczyk, J., Manke, A., Metzl, N., Sabine, C. L., Akl, J., Alin, S. R., Bates, N., Bellerby, R. G. J., Borges, A., Boutin, J., Brown, P. J., Cai, W.-J., Chavez, F. P., Chen, A., Cosca, C., Fassbender, A. J., Feely, R. A., González-Dávila, M., Goyet, C., Hales, B., Hardman-Mountford, N., Heinze, C., Hood, M., Hoppema, M., Hunt, C. W., Hydes, D., Ishii, M., Johannessen, T., Jones, S. D., Key, R. M., Körtzinger, A., Landschützer, P., Lauvset, S. K., Lefèvre, N., Lenton, A., Lourantou, A., Merlivat, L., Midorikawa, T., Mintrop, L., Miyazaki, C., Murata, A., Nakadate, A., Nakano, Y., Nakaoka, S., Nojiri, Y., Omar, A. M., Padin, X. A., Park, G.-H., Paterson, K., Perez, F. F., Pierrot, D., Poisson, A., Ríos, A. F., Santana-Casiano, J. M., Salisbury, J., Sarma, V. V. S. S., Schlitzer, R., Schneider, B., Schuster, U., Sieger, R., Skjelvan, I., Steinhoff, T., Suzuki, T., Takahashi, T., Tedesco, K., Telszewski, M., Thomas, H., Tilbrook, B., Tjiputra, J., Vandemark, D., Veness, T., Wanninkhof, R., Watson, A. J., Weiss, R., Wong, C. S., and Yoshikawa-Inoue, H.: A uniform, quality controlled Surface Ocean $\mathrm{CO}_{2}$ Atlas (SOCAT), Earth Syst. Sci. Data, 5, 125-143, https://doi.org/10.5194/essd-5-125-2013, 2013.

Santana-Casiano, J., González-Dávila, M., and Ucha, I.: Carbon dioxide fluxes in the Benguela upwelling system during winter and spring: A comparison between 2005 and 2006, Deep-Sea Res. Pt. II, 56, 533-541, 2009.

Santana-Casiano, J. M., González-Dávila, M., Rueda, M., Llinás, O., and González-Dávila, E.-F.: The interannual variability of oceanic $\mathrm{CO}_{2}$ parameters in the northeast Atlantic subtropical gyre at the ESTOC site, Global Biogeochem. Cy., 21, GB1015, https://doi.org/10.1029/2006GB002788, 2007.

Santos, A. M. P., Kazmin, A. S., and Peliz, A.: Decadal changes in the Canary upwelling system as revealed by satellite observations: Their impact on productivity, J. Mar. Res., 63, 359-379, 2005.

Santos, F., de Castro, M., Gómez-Gesteira, M., and Alvarez, I.: Differences in coastal and oceanic SST warming rates along the Canary upwelling ecosystem from 1982 to 2010, Cont. Shelf Res., 47, 1-6, 2012. 
Schuster, U., Watson, A., Bates, N., Corbiere, A., Gonzalez-Davila, M., Metzl, N., Pierrot. D., and Santana-Casiano, J. M.: Trends in North Atlantic sea-surface $f \mathrm{CO}_{2}$ from 1990 to 2006, Deep-Sea Res. Pt. II, 56, 620-629, 2009.

Takahashi, T., Olafsson, J., Goddard, J. G., Chipman, D. W., and Sutherland, S.: Seasonal variation of $\mathrm{CO}_{2}$ and nutrients in the high-latitude surface oceans: A comparative study, Glob. Biogeochem. Cy., 7, 843-878, 1993.

Takahashi, T., Sutherland, S., Wanninkhof, R., Sweeney, C., Feely, R., Chipman, D., Hales, B., Friederich, G., Chavez, F., Sabine, C., Watson, A., Bakker, D., Schuster, U., Metzl, N., YoshikawaInoue, H., Ishii, M., Midorikawa, T., Nojiri, Y., Kortzinger, A., Steinhoff, T., Hoppema, M., Olafsson, J., Arnarson, T., Tilbrook, B., Johannessen, T., Olsen, A., Bellerby, A., Wong, C., Delille, B., Bates, N., and de Baar, H.: Climatological mean and decadal change in surface ocean $\mathrm{pCO}_{2}$, and net sea-air $\mathrm{CO}_{2}$ flux over the global oceans, Deep-Sea Res. Pt. II, 56, 554-577, 2009.

Ullman, D. J., McKinley, G. A., Bennington, V., and Dutkiewicz, S.: Trends in the North Atlantic carbon sink: 1992-2006, Glob. Biogeochem. Cy., 23, GB4011, https://doi.org/10.1029/2008GB003383, 2009.
Varela, R., Álvarez, I., Santos, F., de Castro, M., and Gómez-Gesteira, M.: Has upwelling strengthened along worldwide over 1982-2010?, Sci. Rep., 5, 10016, https://doi.org/10.1038/srep10016, 2015.

Wang, Y., Castelao, R. M., and Yuan, Y.: Seasonal variability of alongshore winds and sea surface temperature fronts in Eastern Boundary Current Systems, J. Geophys. Res.-Oceans, 120, 2385-2400, https://doi.org/10.1002/2014JC010379, 2015.

Watson, A., Schuster, U., Bakker, D., Bates, N., Corbière, A., González-Dávila, M., Friedrich, T., Hauck, J., Heinze, C., Johannessen, T., Kortzinger, A., Metzl, N., Olafsson, J., Olsen, A., Oschlies, A., Padin, X. A., Pfeil, B., Santana-Casiano, J. M., Steinhoff, T., Telszewski, M., Rios, A. F., Wallace, D. W., and Wanninkhof, R.: Tracking the variable North Atlantic sink for atmospheric $\mathrm{CO}_{2}$, Science, 326, 1391-1393, https://doi.org/10.1126/science.1177394, 2009.

Yoo, J.-M. and Carton, J. A.: Annual and interannual variation of the freshwater budget in the tropical Atlantic Ocean and the Caribbean Sea, J. Phys. Oceanogr., 20, 831-845, 1990. 